\title{
Regime Type and Bilateral Treaty Formalization:
}

\author{
Do Too Many Cooks Spoil the Soup?
}

\author{
Ana Carolina Garriga \\ Department of Political Science \\ University of Pittsburgh \\ acg11@,pitt.edu, carogarriga@gmail.com \\ Forthcoming Journal of Conflict Resolution
}

[Acceptance date: May 2009]

Abstract.

How does domestic regime type affect bilateral cooperation, and one of its most visible manifestations, bilateral treaties? This paper explains how domestic political regime affects bilateral cooperation and, contrary to the expectations of some scholars, why autocracies should be expected to be more likely than democracies to enter into bilateral treaties. If the preferences of a pair of states are not identical, the sets of agreements that each party would consent to (win-sets) need to overlap for a bilateral treaty to be acceptable. Because additional domestic constraints reduce the size of a country's win-set, autocracies should have broader win-sets than democracies. Therefore, autocratic dyads should be more likely to formalize bilateral treaties than other pairs of states. Based on an original dataset, I present empirical evidence showing that pairs of autocracies are more likely than other pairs of states to enter into agreements formalizing bilateral cooperation.

Keywords: regime type; domestic constraints; bilateral bargaining; treaties; two-level games.

\section{Acknowledgments:}

I am especially grateful to David Bearce and Brian J. Phillips for commenting on several drafts of this paper. I also thank Barry Ames, Ramiro Berardo, Kate Floros, Bill Keech, Scott Morgenstern, Aníbal Pérez Liñán, the members of the World Politics Workshop of the Department of Political Science at the University of Pittsburgh, and two anonymous reviewers for their helpful comments. All replication materials are posted at http://jcr.sagepub.com/. The data and additional tables are posted at http://sites.google.com/site/carogarriga/. 
How does domestic regime type affect bilateral cooperation, and one of its most visible manifestations, bilateral treaties? The literature has contradictory expectations regarding the impact of a country's regime type on cooperation. Whereas some scholars posit a "democratic difference" in international relations, expecting democracies to be more likely than autocracies to cooperate and to enter into agreements, other studies suggest that democratic institutions do not necessarily encourage agreements that formalize cooperation. Furthermore, although empirical evidence suggests that democracies are more likely than autocracies to sign multilateral treaties (for example, Mansfield and Reinhardt 2003:858), the available evidence on bilateral treaties puzzles some scholars as "counter-intuitive" because autocracies seem to sign more treaties than democracies in the noneconomic realm, but fewer in the economic sphere (Remmer 1998:39). Still, the relationship between regime type and bilateral treaties remains unclear.

This paper explains how domestic political regime affects bilateral cooperation and, contrary to the expectations of some scholars, why autocracies should be expected to enter into bilateral treaties more often than democracies. Based on an original dataset, I present empirical evidence showing that pairs of autocracies are more likely than other pairs of states to enter in agreements formalizing bilateral cooperation. In doing so, this paper contributes to the literature in several ways. First, this paper advances a theory about the impact of regime type on bilateral cooperation. To my knowledge, whereas the impact of domestic regime type has been studied in the context of multilateral cooperation (for example, in Mansfield, Milner and Rosendorff 2002; Mansfield and Pevehouse 2006; Vreeland 2008), there are no large-N studies examining the effects of regime type on bilateral cooperation. Second, although this paper draws on the literature on international bargaining, it makes a threefold contribution to that body of research by focusing on the likelihood of reaching bilateral agreements, by analyzing cases of bargaining between two unconstrained parties, and by offering an empirical test of some of its expectations. 
The rest of the paper proceeds as follows: the next section highlights the importance of treaties, particularly of bilateral treaties, for the study of cooperation. The third section reviews the literature analyzing the impact of regime type on cooperation. Section four presents the theory and derives the expectations to be tested. The fifth section describes the data and methods, and presents the results of the statistical analyses. Section six concludes.

\section{WHAT CAN BILATERAL TREATIES TELL US ABOUT COOPERATION?}

Treaties are written instruments formalizing cooperation between the signing states. ${ }^{1}$ The study of treaties can provide insight on international cooperation in several ways. First, although cooperation does not necessarily involve the signature of international instruments (i.e., there can be cooperation without treaties), ${ }^{2}$ the signature of a treaty reveals the will of the parties to be bound by the terms of the agreement. ${ }^{3}$ Although the focus on treaties might overlook cases of tacit cooperation (Milner 1992:469), it avoids classifying as cooperation situations of mere lack of conflict or situations in which the actors' preferences are identical. ${ }^{4}$ Second, since the parties of a treaty are the signing states, the existence of the treaty reflects these states' willingness to cooperate. A state's determination to cooperate can be misrepresented when looking at other indicators of cooperation that depend on the will of third parties or that are affected by exogenous factors. For example, although states may agree in reducing trade barriers in order to increase trade, the effective volume of trade is a consequence of demand and supply conditions, economic environment, and other conditions that escape the parties' control. Third, because treaties are costly, they are better indication of cooperation than mere declarations. Finally, even if some scholars question the actual effect of treaties on state behavior (Downs, Rocke and Barsoom 1996; Mearsheimer 1994/1995), there is substantial evidence indicating that states comply with treaties (Chayes and Chayes 1993, 
1995; Chayes, Chayes and Mitchell 1998; Haas, Keohane and Levy 1993; Mitchell 1994; Simmons 2000).

This paper focuses on bilateral treaties of cooperation. Although multilateral cooperation is theoretically and practically important, the vast majority of international treaties are bilateral (Estevadeordal and Suominen 2007, 2008; Miles and Posner 2008). ${ }^{5}$ Furthermore, bilateral treaties allow scholars to examine bilateral relations without the complications of strategic behavior in multilateral context. Multilateral cooperation involves dynamics whose analysis exceeds the purposes of this paper (for example, coalitions, influence of institutional context, etc.). Finally, bilateral treaties arguably constitute the hardest case to test a theory on cooperation. According to Miles and Posner, bilateral treaties have higher negotiation and enforcement costs than multilateral ones, in part due to the need to be tailored to the parties' needs, and to the impossibility of making reservations (Miles and Posner 2008:5-7). Said costs, in addition to the relative ease associated with noticing defection (in comparison to multilateral treaties), should disincentive for the signature of bilateral treaties. These costs make bilateral treaties good indicators of cooperation among states.

\section{DOES DOMESTIC REGIME TYPE AFFECT COOPERATION?}

Many scholars have analyzed how regime type influences different dimensions of international relations. ${ }^{6}$ Whereas an extensive literature focuses on conflict, ${ }^{7}$ the influence of domestic regime is also being examined in other areas, such as IGO formation or trade agreements. For instance, Mansfield, Milner, and Rosendorff found that democracies are more likely to cooperate on trade policy (2002:477). Notwithstanding, the idea of a "democratic difference" is being questioned in some cases (Dai 2002:163), ${ }^{8}$ and it has not been clearly established in bilateral relations. For example, Remmer found that South American military regimes cooperated extensively 
on a variety of issues. Contrary to expectations, she found that regime similarity and joint authoritarianism are associated with more cooperation in the non-economic realm, ${ }^{9}$ but with less cooperation in the economic sphere (Remmer 1998:39). ${ }^{10}$

In light of the evidence, it is not clear how domestic regime type might affect cooperation and, consequently, the formalization of bilateral treaties of cooperation. Do similar regimes cooperate more with each other than with dissimilar regime types? Do pairs of democracies tend to cooperate more than pairs of autocracies do, as some scholars suggest? What are the characteristics of domestic regime that affect cooperation and the likelihood of reaching bilateral agreements? The literature on international bargaining provides some answers to these questions. In the next paragraphs, I will review those answers and show how this paper contributes to that literature.

\section{DOMESTIC CONSTRAINTS AND INTERNATIONAL BARGAINING}

In order to explain the process and outcomes of international negotiations, several works on international bargaining rely more or less explicitly on domestic regime types, by focusing on the existence of domestic constraints on the executive power.

Schelling posited that in an international negotiation, the party able to say credibly that any agreement they reach needs to be ratified by its legislature has a bargaining advantage (Schelling 1960). According to his argument, a constrained executive should obtain from the other side greater concessions than if it were unconstrained. Putnam (1988) further developed the "Schelling conjecture" (Milner 1997:68). In Putnam's two-level game, domestic constraints affect the size of an executive's win-set in international bargaining, that is, the set of all possible international agreements that would be approved by the majority of the (relevant) domestic actors (Putnam 1988:437). ${ }^{11}$ According to Putnam, the smaller the win-set, the greater risk that negotiations break down $(1988: 438,440)$. 
Some implications of the Schelling-Putnam argument have been modeled and empirically tested (Dai 2006; Iida 1993, 1996; Mansfield, Milner and Rosendorff 2002; Milner 1997; Milner and Rosendorff 1997; Mo 1994, 1995; Pahre 1997; Pahre and Papayoanou 1997). In particular, some works analyze to what extent a domestic constraint entails a bargaining advantage. Whereas Milner does not (formally) find support for the bargaining advantage of needing legislative ratification (Milner 1997), other models incorporate refinements and showed that such advantage exists under certain circumstances (Iida 1993, 1996; Milner and Rosendorff 1997; Mo 1995; Tarar 2001, 2005). However, and as Tarar points out, most of these models rely on a strong simplification: only one of the negotiating parties has a domestic ratification constraint. The other side, not needing domestic ratification, is treated as an autocracy (Tarar 2001:321). ${ }^{12}$ More importantly, the focus of these works is on how differences in regime types' domestic constraints affect the outcomes of bilateral bargaining, that is, which conditions allow a party to obtain an agreement closer to her preferences. The influence of domestic regime on the likelihood of formalizing a treaty, which is the purpose of the present paper, remains underexplored. ${ }^{13}$

In sum, although the influence of regime type on international cooperation has been analyzed from different angles, there are questions that remain unanswered: What is the influence of domestic regime type on the likelihood of formalizing a bilateral treaty? ${ }^{14}$ Are similar regimes more prone to sign treaties with each other than with dissimilar regime types? Do democracies tend to cooperate more with themselves than pairs of autocracies do, as some scholars suggest? What are the expected results of bargaining between two unconstrained parties (two autocracies)? In the next section, I present a theory about the influence of the countries' political regime on the formalization of bilateral treaties.

\section{THEORY AND EXPECTATIONS}


I draw on the literature on international bargaining to explain the likelihood of reaching a bilateral agreement and formalizing a treaty, depending on the parties' regime types.

When do we observe a treaty? For a treaty to be signed, states need to agree on the content of the treaty, and consent to be bound by the terms of the instrument. When states express their consent, the treaty is formalized. ${ }^{15}$ These are the treaties we observe [See Figure 1].

[Figure 1 about here]

Assuming that the preferences of the states are not perfectly aligned, the sets of agreements that each party would consent to (win-sets) need to overlap for a bilateral treaty to be acceptable. If the preferences of the parties were perfectly aligned, the size of the win-set would be irrelevant. However, when the parties' preferences are not aligned the likelihood of win-sets overlap and the size of the overlap between win-sets become a function of the size of the win-sets. In theory, given a certain spatial location of the parties' ideal points, if the win-sets are large enough, they will eventually overlap. Following this logic, the larger the parties' win-sets are, the larger the likelihood of overlapping and the area of the overlap [see Figure 2]. Conversely, if the win-sets are very narrow, the parties' ideal points would need to be very close in order to overlap.

[Figure 2 about here]

This logic is consistent with Putnam's argument regarding an inverse relationship between the size of the parties' win-sets and the risk that international negotiations break down (Putnam 1988:438, 440). Given a pair of states with fixed preferences, if one or both states' win-sets shrink, the area of win-set overlap diminishes. The very likelihood of overlapping win-sets diminishes as well. If the set of acceptable agreements gets too small or even disappears, the risk of failure in the negotiations increases. This explains the positive relationship between the size of the win-set and the likelihood of reaching an agreement (Putnam 1988:450). Although negotiations can fail for other reasons, such as changes in the win-sets during negotiations, ${ }^{16}$ it seems reasonable to posit 
that, holding other factors constant, the larger the win-set, the more likely it is for a treaty to fall in an area of overlap (or acceptability).

My explanation builds on another element of Putnam's argument. Putnam states that domestic constraints affect the size of the executive's win-set. ${ }^{17}$ Unless domestic preferences are perfectly aligned, it seems reasonable to expect for the size of the state's win-set to decrease as the number of domestic constraints increases. These two relationships are graphed in Figure 3: holding other variables constant, domestic constraints are inversely related to the size of the win-set, and the win-set size is inversely related to the possibility of negotiation break down. In other words, the win-set size is directly related to the possibility of success in the bargaining. I therefore hypothesize that the larger the parties' domestic constraints, the less likely it is to observe formalized bilateral treaties.

[Figure 3 about here]

Although this explanation builds on the logic of two-level games, it differs from previous works based on the Schelling-Putnam argument that analyze the distributional outcomes of bargaining. In those models, the likelihood of reaching an agreement is represented by the parties' indifference curves: agreements beyond the indifference curve will not be accepted by at least one of the parties. However, distributional models explain the likely location of the agreement within the win-sets' overlapping area, ${ }^{18}$ treating the indifference curves that limit the win-sets as given. The logic behind these models is that if a party can credibly say that any agreement they reach needs to be ratified by its legislature, said party should be able to obtain agreements that are closer to its ideal point and, conversely, should be able to reject agreements that, being within its win-set, are further away from its ideal point (Putnam 1988; Schelling 1960). This paper explains how domestic constraints affect the location of the parties' indifference curves that will define the win-set overlap area, taking preferences as given. This issue precedes the distributional bargaining: without this initial overlap distributional bargaining should not begin unless the parties misperceive their win-sets. 
Three caveats must be taken into account. First, I assume a negative relationship between domestic constraints and the size of the win-set. The size of the win-set is the causal mechanism assumed to link the independent and dependent variables (domestic constraints and the likelihood of observing a formalized treaty). Determining the actual size of win-sets would demand analyzing each and every instance of agreement and of non-agreement, and it is beyond the scope of the present research. Second, I am not analyzing here the content of the agreements to see whether the Schelling conjecture holds in terms of spatial or distributional outcomes, that is, if the outcome of the negotiation is closer to the preferences of the most constrained negotiator. This paper assumes that the broader the win-set of the parties in a negotiation, the more likely it is to observe a treaty as a result of said negotiation. Finally, I do not argue that domestic constraints are the main determinant of the signature of bilateral treaties. The domestic constraints of the parties in bilateral negotiations are only one of the factors influencing the likelihood of formalizing a treaty.

\section{Domestic constraints and regime type}

Several factors make democracies more constrained than autocracies, narrowing the size of democracy's win-sets. Institutionally, the existence of checks and balances restricts the executives' freedom to conduct foreign policy. In particular, regarding the signature of treaties, constitutions impose ex-ante or ex-post legislative ratification mechanisms. ${ }^{19}$ Beyond the institutional limits, democracies face a series of political and de facto constraints. Opposition parties voice alternative views about foreign policy, demanding sometimes reaching consensus even when those opposition parties lack blocking power in the Congress. Democracies have relatively open channels for interest and pressure groups. Those channels allow different domestic actors (such as lobbying groups, mobilized interest groups, unions, or protesters) to condition the executives' formal freedom to conduct international negotiations. At the level of public opinion, democratic institutions create 
audience costs in the domestic arena (Fearon 1994). Finally, democracies tend to have broader winning coalitions than autocracies: $:^{20}$ democratic leaders need majoritarian consensus to govern (Bueno de Mesquita et al. 2003a) [See Figure 4].

[Figure 4 about here]

Autocracies not only lack legislative ratification mechanisms, but they also are relatively free from other political and de facto constraints. Although there is significant variation across authoritarian regimes, autocracies usually exercise censorship and different forms of repression of opposition groups. Opposition parties are banned or severely restrained in their ability to question autocrats' decisions. Although there are interest and pressure groups in autocracies, the inexistence of open channels for lobbing and/or protesting reduces the frequency of this type of constraints on the executives' decisions. Censorship allows autocratic leaders to misinform the population, lowering audience costs in the domestic arena (Fearon 1994). Even if the population is informed, the use of different forms of repression of opposition groups substantially increases the autocrats' margin of discretion. Finally, although authoritarian regimes need support to gain and stay in power, winning coalitions in autocracies tend to be smaller than winning coalitions in democracies. Therefore, while democratic executives face institutional and political constraints, autocratic executives lack those institutional constraints, and have fewer political and de facto constraints than democracies.

The aforementioned differences between democracies and autocracies shape the size of different regimes' win-sets. With fewer domestic constraints, autocracies should have broader winsets than democracies. If autocracies' win-sets tend to be broader than those of democracies, then the presence of one or two autocracies in a dyad should make the formalization of bilateral treaties more likely. Therefore, one should expect pairs of autocracies (autocratic dyads) to be more likely to 
formalize bilateral treaties than mixed dyads (one democracy and one autocracy) and than pairs of democracies (democratic dyads).

The expectations derived from this theory, and the hypotheses to be tested in this paper, are the following:

Hypothesis 1: Autocratic dyads are more likely than democratic dyads to formalize bilateral treaties.

Hypothesis 2: Autocratic dyads are more likely than mixed dyads to formalize bilateral treaties.

Hypothesis 3: Mixed dyads are more likely than democratic dyads to formalize bilateral treaties.

Hypothesis 4: The greater the domestic constraints of the dyad's parties, the less likely the parties are to formalize a bilateral treaty with each other.

Note that hypothesis 4 suggests that the effect of domestic constraints on the likelihood of formalizing bilateral treaties should be observed not only between regime types, but also within regimes. In other words, although democracies tend to have more domestic constraints than autocracies [see Figure 4], more constrained democracies (or autocracies) should have smaller winsets than democracies (or autocracies) with fewer domestic constraints.

The expectations derived from this theory contrast with arguments that expect a democratic difference, and those stressing the impact of regime homogeneity (Peceny, Beer and Sanchez-Terry 2002; Simon and Gartzke 1996; Werner 2000). On the one hand, if democracies are more prone to cooperate with each other, one could expect democratic dyads to be more likely to formalize that cooperation than autocratic and mixed dyads. On the other hand, some literature suggests that homogeneous dyads should be more prone to reach agreements than mixed dyads (for example, Holsti, Hopmann and Sullivan 1973; Siverson and Emmons 1991). This proposition partially contradicts my hypotheses. ${ }^{21}$ First, I expect a different behavior among homogeneous dyads (hypothesis 1). Second, I contend that it should be easier for autocratic than for mixed dyads to reach an agreement and, consequently, formalize bilateral treaties (hypothesis 2). However, mixed 
dyads should sign more treaties than democratic dyads because autocracies have larger win-sets (hypothesis 3).

\section{EMPIRICAL EVIDENCE}

The preceding section indicates that, because autocracies have fewer constraints than democracies, they should have broader win-sets than democracies do. Holding preferences constant, the larger a party's win-set, the greater the possibility of it overlapping with the other party's win-set and, therefore, of reaching an agreement. If autocracies have larger win-sets, the presence of one or two autocracies in a dyad should increase the likelihood of reaching an agreement and formalizing a bilateral treaty.

\section{STATISTICAL MODELS}

In order to test the hypotheses derived from the theory, I run the following models:

$$
\begin{aligned}
& \text { BT }_{d t}=\beta_{0}+\beta_{1} * \text { DEMOCRATIC DYAD }_{d t}+\beta_{2} * \text { MIXED DYAD }_{d t}+\Sigma \beta_{\mathrm{k}}{ }^{*} \text { CONTROLS }_{d t}+\mathrm{e}_{d t} \\
& \mathrm{BT}_{d t}=\beta_{0}+\beta_{3} * \text { CONSTRAINTS }_{d t}+\Sigma \beta_{k}{ }^{*} \text { CONTROLS }_{\mathrm{dt}}+\mathrm{e}_{d t}
\end{aligned}
$$

The dependent variable is Bilateral treaty $\left(B T_{d t}\right)$. Bilateral treaty is a dichotomous variable that takes the value of 1 when the dyad's parties have signed at least one treaty between them in the year under consideration, and zero otherwise.

Following the Vienna Convention, I have coded as a treaty any written instrument (agreement, treaty, protocol, etc. ${ }^{22}$ ) formalizing cooperation between the signing states. A bilateral treaty is formalized when both parties express their consent to be bound by the treaty they have signed. I consider the date of the signature because it best serves the purposes of the present study. This date gives a common certain date for the dyad that reveals when the agreement was reached. 
Following ratification dates would give different dates for the same treaty, opening the possibility of ratifications when the political regime in the dyad changes. Furthermore, available databases and scholars in the field use the same criterion grounded on practical reasons. I do not include multilateral treaties because the argument put forward in this paper does not translate straightforwardly to multilateral bargaining dynamics. Furthermore, breaking up multilateral bargaining into a set of bilateral negotiations would imply assuming that the dynamics of bilateral and multilateral negotiations are the same and merely additive. ${ }^{23}$

Because this paper presents a theory that is not issue-specific, the appropriate test is on all types of treaties. Therefore, I collected data on bilateral treaties of cooperation on all matters. However, and as a test of robustness, I run the same models on a subsample including treaties on economic cooperation. I collected data on 1,067 bilateral treaties signed between the countries included in the sample, between 1950 and 1979. The sample includes treaties formalizing cooperation on a wide variety of issue areas, such as general economic cooperation, technical cooperation, bilateral regime creation or modification, economic activities and resources, trade, finance, aid, social matters, military cooperation, etc. ${ }^{24}$ The data have been drawn from the $W$ orld Treaty Index (Rohn 1983).

To characterize the dyad's political regime, I employ a set of dichotomous variables (Democratic dyad, Autocratic dyad, and Mixed dyad). Dyads have been coded according to their parties' domestic regime type: Democratic dyad (1=two democracies, $0=$ otherwise), Autocratic dyad (1=two autocracies, $0=$ otherwise), Mixed dyad $(1=$ one democracy and one autocracy, $0=$ otherwise $)$. I follow Przeworski et al.'s rules for coding regimes, according to which regime is a dichotomous variable, coded 0 if the state is a democracy and 1 otherwise (Przeworski et al. 2000). ${ }^{25}$ I expect Democratic dyad and Mixed dyad to be inversely associated with Bilateral treaty. ${ }^{26}$ As a test of robustness for equation I, I use a continuous measure of regime. Polity (dyad sum) is the sum of the Polity IV scores of the 
countries in the dyad. Polity IV's score is a 21-point combined index of regime, ranging from 10 for a highly democratic country to -10 for a highly autocratic state (Marshall and Jaggers 2007). ${ }^{27}$ The dyadic measure may therefore range between 20 and -20. According to the argument put forward in this paper, Polity (dyad sum) is expected to be negatively associated with Bilateral treaty.

In order to test equation II, I use two continuous measures of domestic constraints. Executive constraints (dyad sum) is the sum of the (re-scaled) XCONST scores of the countries in the dyad. Polity IV's XCONST measures "the extent of institutionalized constraints on the decisionmaking powers of chief executives, whether individuals or collectivities" (Marshall and Jaggers 2007:23). Polity VI uses a 7-category scale, ranging from 1 (minimum) to 7 (maximum constraints) [for rules of coding, see Appendix 1]. This variable was rescaled to a 0-6 range to provide meaningful interpretation of the coefficients. Executive constraints (dyad sum) ranges between 0 and 12 and is expected to be negatively associated with Bilateral treaty.

Another way to proxy the magnitude of the domestic constraints on the executive is the size of the winning coalition. As the minimal set of people whose support the incumbent needs in order to remain in power increases, it is likely that the constraints on the executive increase (Bueno de Mesquita et al. 2003a). As with the previous variable, the dyadic variable is Winning coalition (dyad sum), the sum of the scores for the dyad's countries, and it ranges from 0 to 2 . I expect a negative coefficient associated with this variable. The data on was obtained from The Logic of Political Survival Dataset (Bueno de Mesquita et al. 2003b).

In order to proxy the similarity of countries' preferences, I include a measure of affinity. Affinity reflects the degree of agreement between the positions adopted by the members of the dyad in the United Nations General Assembly. Based on General Assembly votes, scores are computed for each dyad using the S index of portfolio similarity (Signorino and Ritter 1999). Affinity is 
measured using the sun2cati item (Gartzke and Jo 2002). It ranges between -1 (complete disagreement with U.S. foreign policy) to 1 (complete alignment) (Gartzke 2006).

I control for a set of factors that may influence the likelihood of formalizing bilateral agreements. Since previous formalized cooperation might affect the likelihood of formalizing present cooperation (Beck, Katz and Tucker 1998:1263), I include a one-year lag of the dependent variable (Bilateral treaty $\left.t_{-1}\right) \cdot{ }^{28}$ As vicinity can increase the incentives or facilitate negotiations to formalize bilateral cooperation, the model includes Border and Distance. Border is a dichotomous variable coded 1 if the dyad shares a common border ${ }^{29}$ and 0 otherwise. Distance is the distance in thousand miles between the countries' capitol cities. Since mutual trade dependency may increase the likelihood of formalizing bilateral treaties, I include Trade dependence, based on Oneal and Russet's measures of interdependence (Dependa and Dependb) (Oneal and Russett 1997). These variables measure country $i$ s trade dependence from country $j$ as state $i$ s exports to state $j$ plus state $j$ s exports to state $i$ over state $i$ 's GDP (that is, $\mathrm{DEPEND}_{i j t}=\left[\mathrm{X}_{i j t}+\mathrm{M}_{i j t}\right] / \mathrm{GDP}_{i t}$ ). Trade dependence is the dyad's minimum value of Dependa and Dependb in the year under analysis. The data for all these variables were obtained using the EUGene software (Bennett and Stam 2000).

Since the size of the state may influence the interest or opportunity to engage in cooperation, I include Size. It reflects the dyad's minimum value of GDP measured in constant 1960 dollars in the year under analysis (World Bank 2008). Finally, I include Year count to account for a temporal trend.

I test the impact of regime type on a dyad's likelihood of formalizing bilateral treaties on a sample of all Latin American and Caribbean countries, ${ }^{30}$ between 1950 and $1979 .{ }^{31}$ The regional sample allows controlling for a series of historic and cultural factors, but still offers significant variance in all the variables of interest. The time period was conditioned by the availability of data about the dependent variable from the same source, ${ }^{32}$ and holds constant the effects of the Cold 
War. I use dyad-year observations, and the $N$ is 7,068 , although data on different independent variables modify the observations used in different models.

[Table 1 about here]

\section{Statistical results}

Given that the data does not exhibit serial correlation, ${ }^{33}$ I ran random effect panel probit analyses on the likelihood of a dyad signing a bilateral treaty in a given year. ${ }^{34}$ The coefficients are presented in Tables 2 and 4. In both tables, Models (a) show the coefficients associated with the main independent variables without controls. These results do not change significantly once controls are included. Since many scholars are skeptical regarding the inclusion of the lagged dependent variable, I show the results omitting and including Bilateral treaty $y_{t-1}$ in Models (b) and (c). The substantive interpretation below is based on Models (c), the ones that include all the controls and that have the best statistical fit, based on the informational criteria.

[Table 2 about here]

Model 1 tests the impact of regime type on the likelihood of formalizing at least one bilateral treaty $(B T=1)$. Consistent with the expectations stated in hypotheses 1 and 2 , the coefficients associated to Democratic dyad and Mixed dyad are both negative and statistically significant, indicating that autocratic dyads are more likely to formalize bilateral treaties than democratic and mixed dyads. Since probit coefficients have no straightforward interpretation, Table 3 shows the marginal effects of Democratic dyad and Mixed dyad holding other variables at their mean (and the other regime dummy at zero). ${ }^{35}$ As shown in Table 3, and under the aforementioned conditions, autocratic dyads that share a border have a baseline probability of signing a bilateral treaty in a given year slightly smaller than .3. This probability is .07 smaller if the dyad is composed by two democracies, and .05 smaller if the dyad is composed by one democracy and one autocracy. Although these magnitudes might 
seem small, they represent a $20-25 \%$ reduction of the baseline probability. In the case of dyads that do not share a border, whereas the baseline probability of observing a bilateral treaty in a given year is .018, democratic dyads have a probability 50\% smaller (.009) than autocratic dyads, and mixed dyads, 33\% smaller (.012) than autocratic dyads that do not share borders, holding other variables at their mean.

[Table 3 about here]

Model 2 provides a robustness check of the idea that less constrained dyads are more likely to sign bilateral treaties. The use of Polity (dyad sum) to proxy the dyad's regime also provides empirical support for the first hypothesis. Increases in the dyadic values of Polity IV are associated with a statistically significant reduction in the likelihood of observing bilateral treaties. Holding all other variables at their mean, the marginal effect of a unit-increase in Polity (dyad sum) is a reduction of .003 in the probability of observing a treaty in a dyad that shares a common border, and of .0004 if the dyad's countries are not contiguous (notice that Polity (dyad sum) ranges between -18 and 20).

To test the third hypothesis, stating that mixed dyads are more likely than democratic dyads to formalize bilateral treaties, I run Models 1 changing the omitted category. ${ }^{36}$ Although the magnitude of the coefficients associated with Democratic dyad and to Mixed dyad might suggest that democratic dyads are less likely to formalize bilateral treaties than mixed dyads (see Models 1 in Table 2), there is no statistically significant difference between democratic and mixed dyads in the likelihood of formalizing bilateral treaties.

Models 3 and 4, shown in Table 4, test the fourth hypothesis stating an inverse relationship between the domestic constraints of the dyad's parties, and the likelihood of formalizing a treaty among these parties. The coefficient associated with Executive constraints (dyad sum) is statistically significant and negative. Holding other variables at their mean, a one-point increase in the sum of the dyad's executive constraints is associated with a reduction of .014 in the probability of signing 
treaties between countries that share a border, and of .002 if the dyad does not include neighboring countries. When the sum of the dyad's winning coalitions is used to proxy domestic constraints, the coefficient is also negative, however, it only achieves a statistical significance of .9 and loses statistical significance when some controls are included (see Model 3(b)). Holding other variables at their mean, a one-point increase in Winning coalition (dyad sum) is associated with a reduction of .049 in the probability of signing treaties between countries that share a border, and of .006 if the dyad does not include neighboring countries.

[Table 4 about here]

As one might expect, Affinity has a positive impact on the likelihood of observing bilateral treaties, suggesting that states with more similar preferences are more likely to enter into bilateral treaties. However, Affinity does not achieve statistical significance in Models $1 .^{37}$ Regarding the impact of the rest of the control variables, holding other variables at their mean, the probability of signing bilateral treaties is .24 larger for dyads that share a border than for dyads that do not. ${ }^{38}$ The coefficient associated with Distance is positive, but only achieves statistical significance in Models 1. The results, however, do not change significantly when Distance is omitted from the models. Trade dependence has no statistically significant impact on the likelihood of signing bilateral treaties. This result (or the effect of the other independent variables) is not altered when using Depend ${ }_{a}$ and Depend $_{b}$ (using either both variables or the sum of them), or when using Depend_max. The size of the economy (measured as Size) has a positive and statistically significant impact on the likelihood of observing bilateral treaties. This impact is also observed if the models include both countries' GDPs, the maximum dyad's value, or the sum of the GDPs. Finally, Year count indicates the existence of a temporal trend towards increasing likelihood of observing bilateral treaties. However, its statistical significance is lost in Models 1, 2 and 4 (c), once the lagged dependent variable is included. 


\section{MAYBE IT IS HOMOGENEITY, NOT AUTOCRACY...}

The statistical analysis provides support for hypotheses 1,2, and 4. These results are at odds with the literature expecting homogeneous dyads to be more prone to cooperation (i.e., Holsti, Hopmann and Sullivan 1973; Siverson and Emmons 1991). For a more direct assessment of the effects of regime similarity on the signature of bilateral treaties, I test an alternative hypothesis: bomogeneous dyads are more likely than mixed dyads to formalize bilateral treaties. ${ }^{39}$ Based on the win-set argument, I do not expect a significant relationship between homogeneity and the likelihood of formalizing treaties because homogeneous dyads blend the diverging effects of democratic and autocratic dyads. In order to test the alternative hypothesis, I run models testing the following equations:

$$
\begin{aligned}
& \mathrm{BT}_{d t}=\beta_{0}+\beta_{4} * \mathrm{MIXED} \mathrm{DYAD}_{d t}+\Sigma \beta_{k}{ }^{*} \mathrm{CONTROLS}_{d t}+\mathrm{e}_{d t} \\
& \mathrm{BT}_{d t}=\beta_{0}+\beta_{5} * \text { CONSTRAINTS DIFFERENCE }_{d t}+\sum \beta_{k}^{*} \text { CONTROLS }_{d t}+\mathrm{e}_{d t}
\end{aligned}
$$

In equation III, the omitted category is homogeneous dyad (combining both democratic and autocratic dyads). Paralleling the first set of models, and as a robustness check, I use the absolute difference in the Polity scores of the dyad's countries Polity (dyad difference) $=\mid$ Polity $_{i}-$ Polity $_{j} \mid$. Smaller values of Polity (dyad difference) proxy more homogeneous dyads, conversely, larger values proxy less homogeneous dyads. I use the same reasoning to build the CONSTRAINTS DIFFERENCE ${ }_{d t}$ variables for equation IV. Executive constraints (dyad difference) and Winning coalition (dyad difference) are the absolute difference of dyad's countries for these variables.

The coefficients obtained using panel probit analyses on the likelihood of signing a bilateral treaty are presented in Table 5.

[Table 5 about here] 
As shown in Table 5, the coefficients associated with Mixed dyad, Polity (dyad difference) and Executive constraints (dyad difference) do not achieve conventional thresholds of statistical significance. This lack of statistical significance also appears when I use other measures built from Polity IV data. I tested Bennet's operationalizations of regime homogeneity: the interaction of both countries' Polity IV scores, and its squared term (Bennett 2006). The coefficients associated with these variables are also negative and do not achieve statistical significance under any specification (not reported). These models, therefore, provide no empirical support for the alternative hypothesis. The coefficients associated with Winning coalition (dyad difference) are statistically significant, but they are consistently positive, ${ }^{40}$ suggesting that the greater the difference in the parties' winning coalitions (that is, as regime homogeneity decreases), the more likely it is to observe a bilateral treaty. ${ }^{41}$

\section{OTHER ROBUSTNESS CHECKS}

In order to test the robustness of these findings, I run all the previous models omitting the treaties on military cooperation and security. Neither the coefficients obtained, nor their statistical significance exhibit noteworthy changes. I also run the previous models controlling for other factors that could affect these results: I include a measure of population, decade dummies, and controls for the existence of conflict in the dyad. Using data from the Correlates of War (2003), I run models controlling for the existence of a MID in the given year or in the previous year (MID_ongoing and MID_ongoing $\left.t_{t-1}\right)$, and for the hostility of the parties (Hostility ${ }_{1}$ and Hostility ${ }_{2}$ ). In all models, the results reported in Tables 2 and 4 maintain their direction, magnitude and statistical significance. Whereas the coefficients associated with the conflict variables do not achieve statistical significance (with ₹values ranging between .3 and .6), population and the decade dummies do. However, the informational criteria reveals that the fit of the models suffer with the inclusion of any of these controls. ${ }^{42}$ 


\section{CONCLUSIONS}

This paper's argument draws on two propositions in Putnam's article: the incidence of domestic constraints on the size of the executive's win-set, and the inverse relationship between the size of the win-set and the risk that negotiations break down (Putnam 1988:438, 440). I argued that as a state's win-set increases, so do the possibilities of overlapping with the other state's win-set and, therefore, of reaching an agreement. If, holding other variables constant, domestic constraints are inversely related to the size of the win-set, and the win-set size is directly related to the possibility of success in the bargaining, I hypothesized that the larger the parties' domestic constraints are, the less likely it is to observe formalized bilateral treaties. Because autocracies are less constrained than democracies, one should expect bilateral treaties to be more likely among autocratic than among democratic or mixed dyads. The statistical analysis on a sub-regional sample provides empirical support to three of the hypotheses derived from this argument: autocratic dyads seem to be more likely to formalize bilateral treaties than democratic and mixed dyads, and less constrained dyads are more likely to formalize bilateral treaties than more constrained ones. These results are robust to different specifications and different measurements of the regime and constraints variables. Once interest similarity, geographical proximity, trade dependence and size of the economy are controlled for, regime type has a substantive, independent and statistically significant impact on the likelihood of formalizing bilateral treaties.

These findings represent a contribution to the literature on international bargaining and to the literature on international treaties. Regarding the literature on international bargaining, this paper extends the logic of two-level games to an instance that precedes the distributional bargaining: not only the outcome of the bargaining, but also the mere possibility of overlapping win-sets are 
depend on the parties' domestic constraints. The results suggest that one should expect more cooperation to materialize in bilateral treaties among less constrained parties, independently of the distribution of the payoffs. This suggests another channel through which domestic constraints can influence international agreements. Second, although the theory is grounded on the two-level games logic, this paper does not rely on the assumption of one constrained party in negotiations (as most of the literature modeling two-level games does). The expectations for instances where both sides are unconstrained contrast with arguments that posit a democratic difference, and with those stressing the impact of regime homogeneity. Third, by considering domestic constraints as a continuous variable, and not a characteristic that distinguishes democracies from autocracies, the theory is able to predict variations in each regime type. This is a more realistic depiction of the variation observed across democracies and across autocracies. Finally, these findings provide suggestive insights on the effect of regime type in general (as opposed to sectoral) international cooperation.

Regarding the literature on international treaties, this paper offers evidence suggesting that regime type, and not mere regime homogeneity (Peceny, Beer and Sanchez-Terry 2002; Simon and Gartzke 1996; Werner 2000), can make formalizing agreements easier. Pairs of autocracies should be expected to be more likely sign bilateral treaties than pairs of democracies. These findings pose interesting questions for further research. For example, using a global sample Mansfield, Milner and Rosendorff (2002) found that democracies are more likely to enter into multilateral economic treaties. This finding contrasts with this paper's results. ${ }^{43}$ Can regime type have different effects on the formalization of bilateral and of multilateral treaties? Is this discrepancy a consequence of bargaining dynamics, or of a selection of issues to be negotiated bilaterally or multilaterally? Are bilateral treaties a substitute for multilateral cooperation? What is the "architecture" (Raustiala 2005) of the treaties signed by different regime types? Do treaties signed by democratic, mixed or 
autocratic dyads have a different fate? How do changes in the parties' domestic regimes affect compliance? These questions justify additional efforts in data collection to test alternative explanations.

A final word of caveat regarding the results' possible limits of generalization: Although the argument presented in this paper should be valid for different time periods and across geographic regions, the sample used for the empirical test has geographic and temporal limits that might have an influence on the results. Although I do not have particular expectations regarding the effects that the sample's idiosyncrasy might have, further research should examine whether the dynamics of international bargaining were affected by the end of the Cold War, or by regional attributes. 
Figure 1: Relations between the sets of acceptable, signed, and formalized treaties.

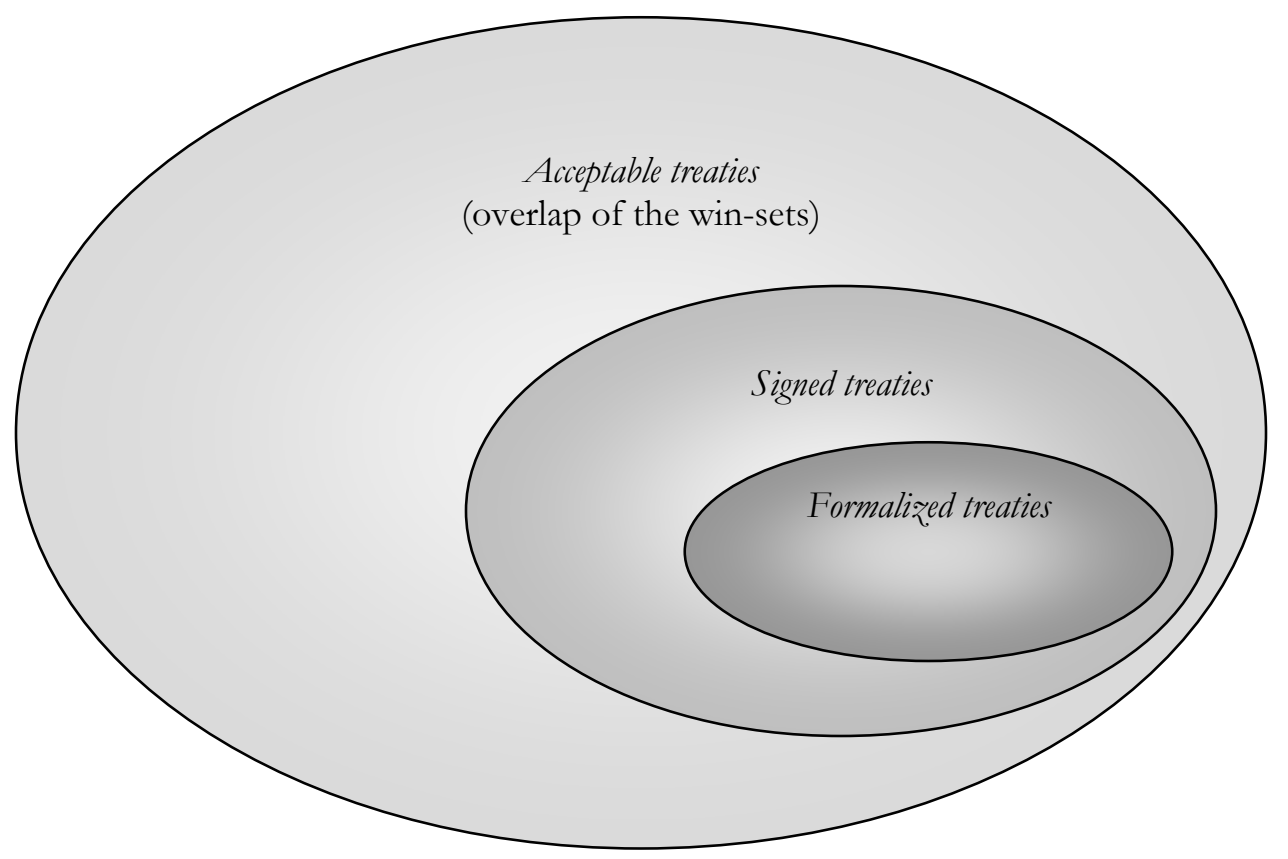


Figure 2: Size of the win-sets and set of acceptable treaties, holding preferences constant



Holding ideal points constant, as A's win-set gets larger (from $\boldsymbol{\alpha}$ to $\boldsymbol{\beta}$ ), the likelihood of overlapping win-sets and the area of said overlapping increase. The area of overlapping $(\boldsymbol{\gamma})$ is the set of possible agreements or acceptable treaties between the two parties. 
Figure 3: Relationship between domestic constraints, win-size size, and success in bargaining

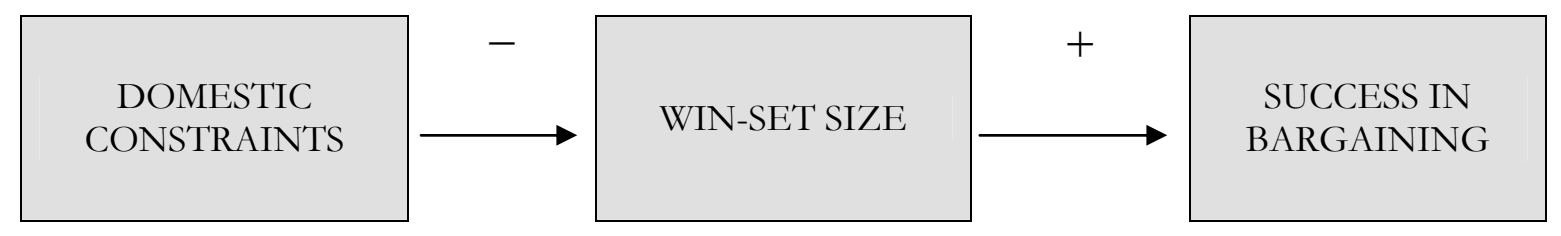

Notes: The signs reflect a direct $(+)$ or inverse $(-)$ relationship among the magnitude of the variables. Success in bargaining is assumed to be inversely related to the possibility of negotiation break down (Putnam 1988:438, 440). 
Figure 4: Regime type and level of domestic constraints

\begin{tabular}{|c|c|c|c|}
\hline \multirow{2}{*}{ Regime type } & \multicolumn{2}{|c|}{ Principal domestic constraints (examples) } & \multirow{2}{*}{$\begin{array}{l}\text { Level of } \\
\text { domestic } \\
\text { constraints }\end{array}$} \\
\hline & Institutional & Political and de facto & \\
\hline DEMOCRACIES & $\begin{array}{l}\text { Ex-ante or ex-post } \\
\text { ratification mechanisms }\end{array}$ & $\begin{array}{c}\text { Opposition parties } \\
\text { Interest and pressure groups } \\
\text { Audience costs } \\
\text { Larger winning coalition }\end{array}$ & High \\
\hline AUTOCRACIES & $\begin{array}{l}\text { Inexistent or rarely } \\
\text { followed }\end{array}$ & $\begin{array}{c}\text { Fewer interest and pressure } \\
\text { groups } \\
\text { Lower audience costs } \\
\text { Smaller winning coalition }\end{array}$ & Low \\
\hline
\end{tabular}


Table 1. Descriptive statistics

\begin{tabular}{lccccc}
\hline \multicolumn{1}{c}{ Variable } & Obs & Mean & Std. Dev. & Min & Max \\
\hline Bilateral treaty & 7068 & .069 & .253 & 0 & 1 \\
Bilateral treaty t-1 $^{\prime}$ & 6792 & .071 & .258 & 0 & 1 \\
Autocratic dyad & 6236 & .291 & .454 & 0 & 1 \\
Democratic dyad & 6236 & .203 & .403 & 0 & 1 \\
Mixed dyad & 6236 & .506 & .500 & 0 & 1 \\
Polity (dyad sum) & 5441 & -.250 & 8.653 & -18 & 20 \\
Polity (dyad difference) & 5441 & 7.031 & 5.143 & 0 & 20 \\
Executive constraints (dyad sum) & 6310 & 4.546 & 2.926 & 0 & 12 \\
Executive constraints (dyad difference) & 6310 & 2.350 & 1.852 & 0 & 6 \\
Winning coalition (dyad sum) & 6878 & 1.045 & .414 & 0 & 2 \\
Winning coalition (dyad difference) & 6878 & .326 & .256 & 0 & 1 \\
Affinity & 7065 & .854 & .230 & -.695 & 1 \\
Border & 7068 & .123 & .328 & 0 & 1 \\
Distance & 7068 & 1.929 & 1.152 & .109 & 4.697 \\
Trade dependence & 6904 & .0005 & .002 & 0 & .029 \\
Size & 7068 & 7.308 & .355 & 6.826 & 8.435 \\
Year count & 7068 & 15.840 & 8.506 & 0 & 29 \\
\hline
\end{tabular}


Table 2. Random-effects panel probit estimates of the likelihood of signing a bilateral treaty (24 Latin American and Caribbean countries, 1950-1979)

\begin{tabular}{|c|c|c|c|c|c|c|}
\hline & \multicolumn{3}{|c|}{ Models 1} & \multicolumn{3}{|c|}{ Models 2} \\
\hline & $1(\mathrm{a})$ & 1(b) & $1(\mathrm{c})$ & $2(\mathrm{a})$ & 2(b) & $2(\mathrm{c})$ \\
\hline Intercept & $\begin{array}{c}-1.967 * * * \\
(-19.23)\end{array}$ & $\begin{array}{c}-5.561 * * * \\
(-4.19)\end{array}$ & $\begin{array}{c}-5.440 * * * \\
(-4.31)\end{array}$ & $\begin{array}{c}-2.036^{* * *} \\
(-23.84)\end{array}$ & $\begin{array}{c}-7.412 * * * \\
(-5.64)\end{array}$ & $\begin{array}{c}-7.089 * * * \\
(-5.66)\end{array}$ \\
\hline Democratic dyad & $\begin{array}{c}-.264 * * * \\
(-2.57)\end{array}$ & $\begin{array}{c}-.209 * * \\
(1.96)\end{array}$ & $\begin{array}{r}-.226 * * \\
(-2.12)\end{array}$ & & & \\
\hline Mixed dyad & $\begin{array}{c}-.169 * * \\
(-2.20)\end{array}$ & $\begin{array}{l}-.143^{*} \\
(-1.85)\end{array}$ & $\begin{array}{l}-.147^{*} \\
(-1.90)\end{array}$ & & & \\
\hline Polity (dyad sum) & & & & $\begin{array}{c}-.011 * * \\
(-2.03)\end{array}$ & $\begin{array}{c}-.010^{* *} \\
(-1.99)\end{array}$ & $\begin{array}{c}-.010^{* *} \\
(-1.99)\end{array}$ \\
\hline Affinity & & $\begin{array}{c}.008 \\
(0.04)\end{array}$ & $\begin{array}{c}.050 \\
(0.24)\end{array}$ & & $\begin{array}{c}.579 * * * \\
(2.75)\end{array}$ & $\begin{array}{c}.602 * * * \\
(2.84)\end{array}$ \\
\hline $\mathrm{BT}_{t-1}$ & & & $\begin{array}{c}.247 * * * \\
(2.79)\end{array}$ & & & $\begin{array}{c}.253 * * * \\
(2.37)\end{array}$ \\
\hline Border & & $\begin{array}{c}1.608^{* * *} \\
(9.32)\end{array}$ & $\begin{array}{c}1.509 * * * \\
(9.07)\end{array}$ & & $\begin{array}{c}1.448^{* * *} \\
(8.35)\end{array}$ & $\begin{array}{c}1.350^{* * *} \\
(8.05)\end{array}$ \\
\hline Distance & & $\begin{array}{l}.112^{* *} \\
(1.95)\end{array}$ & $\begin{array}{l}.106^{*} \\
(1.94)\end{array}$ & & $\begin{array}{c}.037 \\
(0.64)\end{array}$ & $\begin{array}{c}.034 \\
(0.62)\end{array}$ \\
\hline Trade dependence & & $\begin{array}{r}-28.049 \\
(-1.43)\end{array}$ & $\begin{array}{c}-27.972 \\
(-1.42)\end{array}$ & & $\begin{array}{r}-31.061 \\
(-1.52)\end{array}$ & $\begin{array}{c}-31.282 \\
(-1.53)\end{array}$ \\
\hline Size & & $\begin{array}{l}.423 * * \\
(2.33)\end{array}$ & $\begin{array}{l}.418^{* *} \\
(2.42)\end{array}$ & & $\begin{array}{c}.621 * * * \\
(3.53)\end{array}$ & $\begin{array}{c}.585^{* * *} \\
(3.52)\end{array}$ \\
\hline Year count & & $\begin{array}{c}.010^{* * *} \\
(2.47)\end{array}$ & $\begin{array}{l}.006 \\
(1.42)\end{array}$ & & $\begin{array}{l}.008^{*} \\
(1.90)\end{array}$ & $\begin{array}{l}.005 \\
(1.09)\end{array}$ \\
\hline Observations & 6236 & 6234 & 6001 & 5441 & 5332 & 5130 \\
\hline Log likelihood & -1276.8421 & -1233.2249 & -1202.5777 & -1061.4715 & -979.50038 & -955.71604 \\
\hline Wald $\chi^{2}$ & 7.70 & 107.23 & 124.90 & 4.11 & 101.11 & 117.31 \\
\hline Prob $>\chi^{2}$ & 0.0213 & 0.0000 & 0.0000 & 0.0426 & 0.0000 & 0.0000 \\
\hline AIC & 2561.684 & 2486.45 & 2427.155 & 2128.943 & 1977.001 & 1931.432 \\
\hline $\mathrm{BIC}$ & 2588.637 & 2553.827 & 2500.852 & 2148.748 & 2036.234 & 1996.861 \\
\hline
\end{tabular}

Notes: Dependent variable is bilateral treaty. Estimation using $x$ tprobit (Stata 10). $Z$ values reported in parenthesis. Two-tailed test statistical significance is indicated as follows: ${ }^{*} p<0.10,{ }^{* *} p<0.05$, $* * * p<0.01$. 
Table 3. Marginal effects after random-effects panel probit, holding all other variables at their mean except noted otherwise

\begin{tabular}{|c|c|c|c|c|}
\hline & \multicolumn{2}{|c|}{ Border $=1$} & \multicolumn{2}{|c|}{ Border $=0$} \\
\hline & $\begin{array}{c}\mathrm{y}=\operatorname{Pr}(\mathrm{DV}=1 \\
\left.\text { assuming } \mathrm{u} \_\mathrm{i}=0\right)\end{array}$ & $\begin{array}{l}\mathrm{dy} / \mathrm{dx} \\
\text { (₹) }\end{array}$ & $\begin{array}{c}\mathrm{y}=\operatorname{Pr}(\mathrm{DV}=1 \\
\left.\text { assuming } \mathrm{u} \_\mathrm{i}=0\right)\end{array}$ & $\begin{array}{l}\mathrm{dy} / \mathrm{dx} \\
\text { (Z) }\end{array}$ \\
\hline Democratic dyad $(\dagger)$ & .282 & $\begin{array}{c}-.073 * * * \\
(-2.14)\end{array}$ & .019 & $\begin{array}{c}-.009 * * \\
(-2.03)\end{array}$ \\
\hline Mixed dyad $(\dagger)$ & .272 & $\begin{array}{l}-.049 * \\
(-1.86)\end{array}$ & .017 & $\begin{array}{l}-.006^{*} \\
(-1.72)\end{array}$ \\
\hline Polity IV (dyad sum) & .219 & $\begin{array}{r}-.003 * * \\
(-1.96)\end{array}$ & .017 & $\begin{array}{c}-.0004^{* *} \\
(-1.91)\end{array}$ \\
\hline $\begin{array}{l}\text { Executive constraints } \\
\text { (dyad sum) }\end{array}$ & .231 & $\begin{array}{c}-.014^{* * *} \\
(-3.28)\end{array}$ & .019 & $\begin{array}{r}-.002 * * * \\
(-2.96)\end{array}$ \\
\hline $\begin{array}{l}\text { Winning coalition } \\
\text { (dyad sum) }\end{array}$ & .237 & $\begin{array}{l}-.049 * \\
(-1.84)\end{array}$ & .016 & $\begin{array}{l}-.006^{*} \\
(-1.74)\end{array}$ \\
\hline
\end{tabular}

Notes: Estimation using $m f x$ command (Stata 10). Model specification as in Models (c); control variables not reported. $Z$ values reported in parenthesis. Two-tailed test statistical significance is indicated as follows: ${ }^{*} p<0.10,{ }^{* *} p<0.05,{ }^{* * *} p<0.01$.

$(\dagger) \mathrm{dy} / \mathrm{dx}$ is for discrete change of dichotomous variable from 0 to 1 , holding the other regime dichotomous variable at zero. 
Table 4. Random-effects panel probit estimates of the likelihood of signing a bilateral treaty (24

Latin American and Caribbean countries, 1950-1979)

\begin{tabular}{|c|c|c|c|c|c|c|}
\hline & \multicolumn{3}{|c|}{ Models 3} & \multicolumn{3}{|c|}{ Models 4} \\
\hline & $3(\mathrm{a})$ & $3(b)$ & $3(\mathrm{c})$ & $4(\mathrm{a})$ & 4(b) & $4(c)$ \\
\hline Intercept & $\begin{array}{c}-1.774 * * * \\
(-17.37)\end{array}$ & $\begin{array}{c}-7.173 * * * \\
(-5.95)\end{array}$ & $\begin{array}{c}-6.976^{* * *} \\
(-6.11)\end{array}$ & $\begin{array}{c}-1.865^{* * *} \\
(-16.16)\end{array}$ & $\begin{array}{c}-6.561 * * * \\
(-5.43)\end{array}$ & $\begin{array}{c}-6.414 * * * \\
(-5.61)\end{array}$ \\
\hline $\begin{array}{l}\text { Exec. constraints } \\
\text { (dyad sum) } \\
\text { Winning coalition } \\
\text { (dyad sum) }\end{array}$ & $\begin{array}{c}-.047 * * * \\
(-3.28)\end{array}$ & $\begin{array}{c}-.044 * * * \\
(-3.08)\end{array}$ & $\begin{array}{c}-.048^{* * *} \\
(-3.34)\end{array}$ & $\begin{array}{c}-.194 * * * \\
(-2.45)\end{array}$ & $\begin{array}{l}-.133 \\
(-1.53)\end{array}$ & $\begin{array}{l}-.159 * \\
(-1.84)\end{array}$ \\
\hline Affinity & & $\begin{array}{r}.398^{* *} \\
(2.17)\end{array}$ & $\begin{array}{r}.426 * * \\
(2.31)\end{array}$ & & $\begin{array}{r}.422^{* *} \\
(2.34)\end{array}$ & $\begin{array}{c}.444 * * * \\
(2.44)\end{array}$ \\
\hline $\mathrm{BT}_{\mathrm{t}-1}$ & & & $\begin{array}{c}.286^{* * *} \\
(3.22)\end{array}$ & & & $\begin{array}{c}.267 * * * \\
(3.09)\end{array}$ \\
\hline Border & & $\begin{array}{c}1.454 * * * \\
(8.85)\end{array}$ & $\begin{array}{c}1.347 * * * \\
(8.56)\end{array}$ & & $\begin{array}{c}1.537 * * * \\
(9.12)\end{array}$ & $\begin{array}{c}1.431 * * * \\
(8.88)\end{array}$ \\
\hline Distance & & $\begin{array}{l}.057 \\
(1.05)\end{array}$ & $\begin{array}{l}.052 \\
(1.02)\end{array}$ & & $\begin{array}{l}.079 \\
(1.44)\end{array}$ & $\begin{array}{c}.073 \\
(1.42)\end{array}$ \\
\hline Trade dependence & & $\begin{array}{c}-28.621 \\
(-1.44)\end{array}$ & $\begin{array}{c}-28.151 \\
(-1.41)\end{array}$ & & $\begin{array}{c}-28.659 \\
(-1.47)\end{array}$ & $\begin{array}{r}-28.747 \\
(-1.47)\end{array}$ \\
\hline Size & & $\begin{array}{c}.629 * * * \\
(3.83)\end{array}$ & $\begin{array}{c}.616^{* * *} \\
(3.97)\end{array}$ & & $\begin{array}{c}.526 * * * \\
(3.19)\end{array}$ & $\begin{array}{c}.524 * * * \\
(3.36)\end{array}$ \\
\hline Year count & & $\begin{array}{c}.013^{* * *} \\
(3.48)\end{array}$ & $\begin{array}{r}.009 * * \\
(2.20)\end{array}$ & & $\begin{array}{l}.009 * * \\
(2.27)\end{array}$ & $\begin{array}{l}.005 \\
(1.17)\end{array}$ \\
\hline Observations & 6310 & 6200 & 5956 & 6878 & 6794 & 6540 \\
\hline Log likelihood & -1330.0303 & -1237.391 & -1204.8449 & -1398.1884 & -1310.6048 & -1278.6216 \\
\hline Wald $\chi^{2}$ & 10.75 & 130.68 & 152.09 & 6.02 & 116.14 & 137.17 \\
\hline Prob $>\chi^{2}$ & 0.0010 & 0.0000 & 0.0000 & 0.0142 & 0.0000 & 0.0000 \\
\hline AIC & 2666.061 & 2492.782 & 2429.69 & 2802.377 & 2639.21 & 2577.243 \\
\hline $\mathrm{BIC}$ & 2686.31 & 2553.373 & 2496.611 & 2822.885 & 2700.624 & 2645.1 \\
\hline
\end{tabular}

Notes: Dependent variable is bilateral treaty. Estimation using $x$ tprobit (Stata 10). $Z$ values reported in parenthesis. Two-tailed test statistical significance is indicated as follows: ${ }^{*} p<0.10,{ }^{* *} p<0.05$, $* * * p<0.01$. 


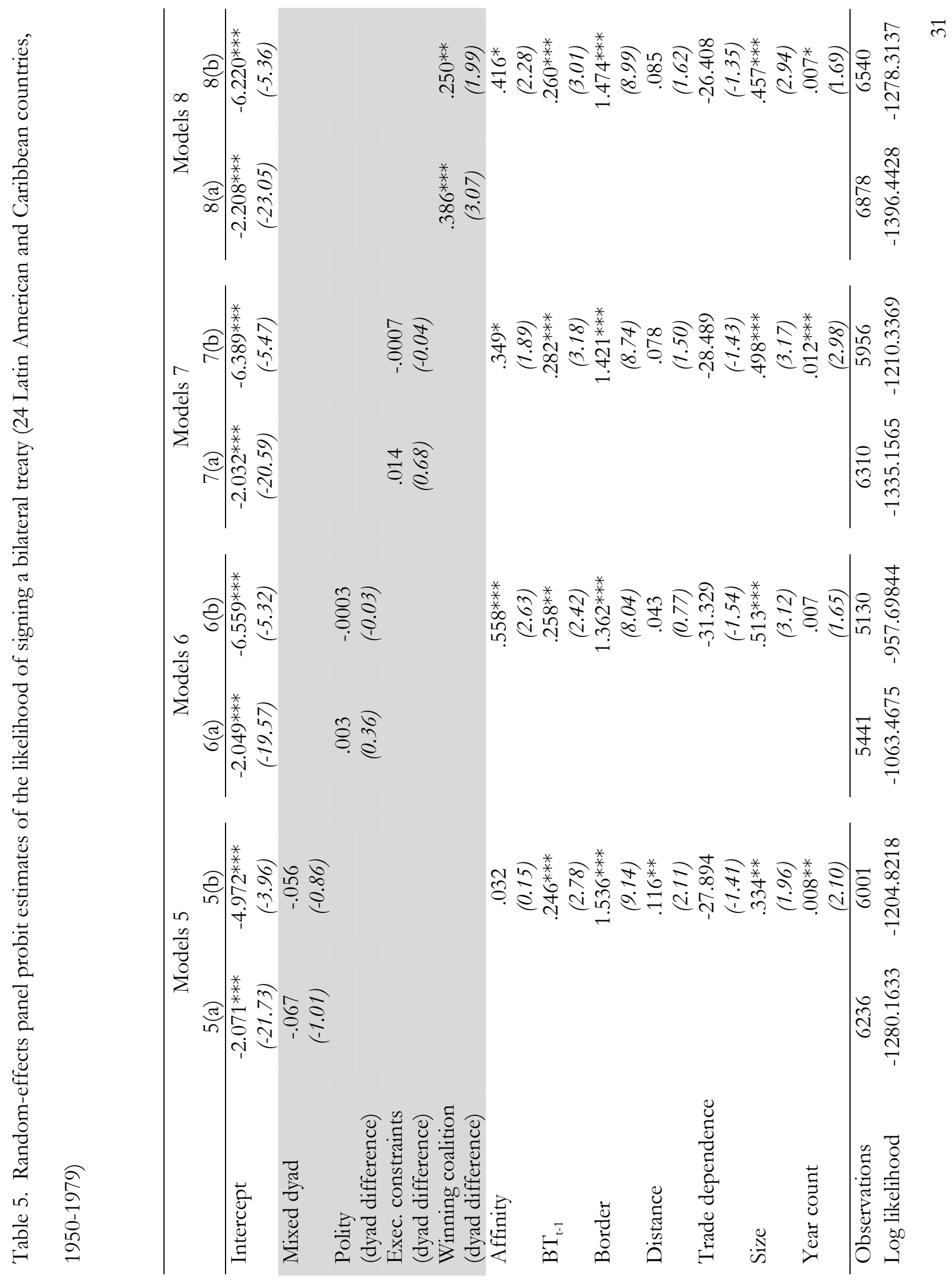




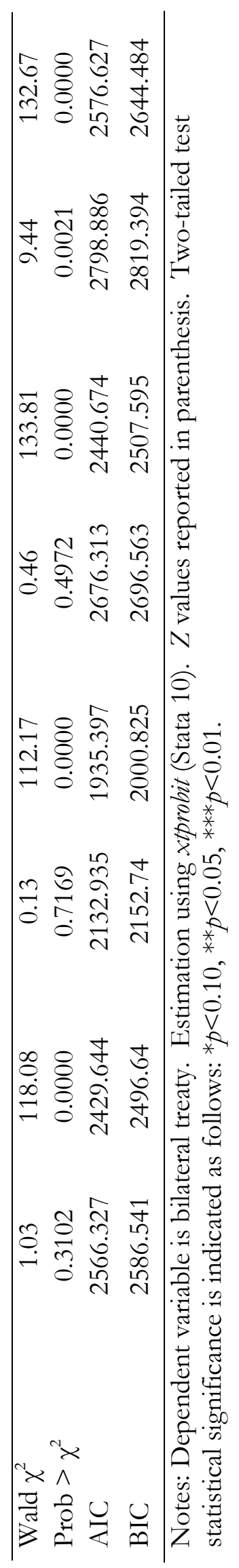




\section{APPENDIX 1: Rules of coding for Polity IV's Executive constraints (XCONST)}

This appendix is an excerpt of the Polity IV Dataset User's Manual (Marshall and Jaggers 2007:23-24). For further details, see its Addendum B, pages 63-67.

XCONST measures the "the extent of institutionalized constraints on the decision-making powers of chief executives, whether individuals or collectivities" (Marshall and Jaggers 2007:23). This variable is measured using a seven-category scale. The categories are defined as follows:

(1) Unlimited Authority: Absence of regular limitations on the executive's actions. Examples: constitutional restrictions on executive action are ignored; constitution is frequently revised or suspended at the executive's initiative; lack of legislature or, if present, it is called and dismissed at the executive's pleasure; the legislature cannot initiate legislation or veto or suspend acts of the executive; rule by decree is repeatedly used; etc.

(2) Intermediate Category

(3) Slight to Moderate Limitation on Executive Authority: There are some real but limited restraints on the executive. Examples: the legislature initiates some categories of legislation or blocks implementation of executive acts and decrees; attempts by the executive to change some constitutional restrictions fail and are not adopted; the ruling party initiates some legislation or takes some administrative action independently of the executive; there is an independent judiciary; etc.

(4) Intermediate Category

(5) Substantial Limitations on Executive Authority: The executive has more effective authority than any accountability group but is subject to substantial constraints by them. Examples: a legislature or party council often modifies or defeats executive proposals for action; a council or legislature sometimes refuses funds to the executive; the accountability group makes important appointments to administrative posts; etc. 


\section{(6) Intermediate Category}

(7) Executive Parity or Subordination: Accountability groups have effective authority equal to or greater than the executive in most areas of activity. Examples: a legislature, ruling party, or council of nobles initiates much or most important legislation; the executive is chosen by the accountability group and is dependent on its continued support to remain in office; in multi-party democracies, there is chronic "cabinet instability." 


\section{REFERENCES}

Abbott, Kenneth W., Robert O. Keohane, Andrew Moravcsik, Anne-Marie Slaughter, and Duncan Snidal. 2000. The Concept of Legalization. International Organization 54 (3):401-19.

Alvarez, Jose E. 2001. Do Liberal States Behave Better? A Critique of Slaughter's Liberal Theory. European Journal of International Law 12 (2):183-247.

Beck, Nathaniel, Jonathan N. Katz, and Richard Tucker. 1998. Taking Time Seriously: Time-SeriesCross-Section Analysis with a Binary Dependent Variable. American Journal of Political Science 42 (4):1260-88.

Bennett, D. Scott. 2006. Toward a Continuous Specification of the Democracy-Autocracy Connection. International Studies Quarterly 50:313-38.

Bennett, D. Scott, and Allan Stam. 2000. EUGene: A Conceptual Manual. International Interactions 26 (2):179-204.

Bueno de Mesquita, Bruce, and David Lalman. 1992. War and Reason: Domestic and International Imperatives. New Haven: Yale University Press.

Bueno de Mesquita, Bruce, James D. Morrow, Randolph M. Siverson, and Alastair Smith. 2003a. The Logic of Political Survival Cambridge, MA: The MIT Press.

Bueno de Mesquita, Bruce, Alastair Smith, Randolph M. Siverson, and James D. Morrow. 2003b. The Logic of Political Survival Data Source. http://www.nyu.edu/gsas/dept/politics/data/bdm2s2/Logic.htm.

Busch, Marc L. 2000. Democracy, Consultation and the Paneling of Disputes under GATT. Journal of Conflict Resolution 44 (August):425-46.

Chayes, Abram, and Antonia Handler Chayes. 1993. On Compliance. International Organization 47 (2):175-205.

- 1995. The New Sovereignty: Compliance with International Regulatory Agreements. Cambridge, MA: Harvard University Press.

Chayes, Abram, Antonia Handler Chayes, and Ronald B. Mitchell. 1998. Managing Compliance: A Comparative Perspective. In Engaging Countries: Strengthening Compliance with International Environment Accords, ed. E. Brown Weiss and H. K. Jacobson. Cambridge, MA: MIT Press.

Correlates of War. 2003. COW Extra-State War Data, 1816-1997 (v3.0). http://dvn.iq.harvard.edu/dvn/dv/cow/faces/study/StudyPage.xhtml?studyId=616\&rvn= 1.

Dai, Xinyuan. 2002. Political Regimes and International Trade: The Democratic Difference Revisted. American Political Science Review 96 (1):159-65.

- 2006. Dyadic Myth and Monadic Advantage. Conceptualizing the Effect of Democratic Constraints on Trade. Journal of Theoretical Politics 18 (3): 267-97.

Downs, George W., David M. Rocke, and Peter N. Barsoom. 1996. Is the Good New About Compliance Good News About Cooperation? International Organization 50 (3):379-406.

Doyle, Michael W. 1986. Liberalism and World Politics. American Political Science Review 80 (4):115169.

Earnest, David C. 2008. Coordination in Large Numbers: An Agent-Based Model of International Negotiations. International Studies Quarterly 52:363-82.

Estevadeordal, Antoni, and Kati Suominen. 2007. Sequencing Regional Trade Integration and Cooperation Agreements: Describing a Dataset for a New Research Agenda. Integration \& Trade 26:53-96. 
- 2008. Sequencing Regional Trade Integration and Cooperation Agreements. The World Economy 31 (1):112-40.

Farber, Henry S., and Joanne Gowa. 1995. Polities and Peace. International Security 20 (2):123-46.

Fearon, James D. 1994. Domestic Political Audiences and the Escalation of International Disputes. American Political Science Review 88:577-92.

Fortna, Virginia Page. 2004. Peace Time: Cease-Fire Agreements and the Durability of Peace. Princeton, NJ: Princeton University Press.

Gartzke, Erik. 2006. The Affinity of Nations Index, 1946-2002 [Codebook Version 4.0]. New York: Columbia University.

Gartzke, Erik, and D-J. Jo. 2002. The Affinity of Nations Index, 1946-1996. From Erik Garzke's webpage http://www.columbia.edu/ eg589.

Gaubatz, Kurt Taylor. 1996. Democratic States and Commitment in International Relations. International Organization 50 (1): 109-39.

Geddes, Barbara. 1999. What Do We Know About Democratization After Twenty Years? Annual Review of Political Science 2:115-44.

Gleditsch, Nils Petter, and Havard Hegre. 1997. Peace and Democracy: Three Levels of Analysis. Journal of Peace Research 41 (2):283-310.

Haas, Peter M., Robert O. Keohane, and Marc A. Levy, eds. 1993. Institutions for the Earth: Sources of Effective International Environmental Protection 4th printing ed. Cambridge, MA: MIT Press.

Holsti, Ole R., Terrence Hopmann, and John Sullivan. 1973. Unity and Disintegration in International Alliances: Comparative Studies. New York, NY: Wiley.

Iida, Keisuke. 1993. When and How Do Domestic Constraints Matter? Two-Level Games with Uncertainty. Journal of Conflict Resolution 37 (4):403-26. . 1996. Involuntary Defection in Two-Level Games. Public Choice 89:283-303.

Kaufman, Robert R. 1985. Democratic and Authoritarian Responses to the Debt Issue: Argentina, Brazil, Mexico. International Organization 39 (3):573-03.

Kono, Daniel Y. 2006. Optimal Obfuscation: Democracy and Trade Policy Transparency. American Political Science Review 100 (3):369-84.

Lake, David. A. . 1992. Powerful Pacifists: Democratic States and War. American Political Science Review 86:24-37.

Mansfield, Edward D., Helen V. Milner, and B. Peter Rosendorff. 2000. Free to Trade: Democracies, Autocracies, and International Trade. American Political Science Review 94 (2):30521.

- 2002. Why Democracies Cooperate More: Electoral Control and International Trade Agreements. International Organization 56 (3 ):477-513.

Mansfield, Edward D., and Jon C. Pevehouse. 2006. Democratization and International Organizations. International Organization 60 (1):137-67.

Mansfield, Edward D., and Eric Reinhardt. 2003. Multilateral Determinants of Regionalism: The Effects of GATT/WTO on the Formation of Preferential Trading Arrangements. International Organization 57 (4):829-62.

Marshall, Monty G., and Keith Jaggers. 2007. Polity IV Project: Dataset Users' Manual. College Park: University of Maryland.

Mearsheimer, John J. 1994/1995. The False Promise of International Institutions. International Security 19 (3):5-49.

Miles, Thomas J., and Eric A. Posner. 2008. Which States Enter into Treaties, and Why? In John M. Olin Law \& Economics Working Paper No. 420 (2D Series); Public Law and Legal Theory Working Paper No. 225. Chicago, IL: University of Chicago - The Law School. 
Milner, Helen V. 1992. International Theories of Cooperation Among Nations: Strengths and Weaknesses. World Politics 44 (3):466-96.

1997. Interests, Institutions, and Information: Domestic Politics and International Relations Princeton, NJ: Princeton University Press.

Milner, Helen V., and Keiko Kubota. 2005. Why the Move to Free Trade? Democracy and Trade Policy in the Developing Countries. International Organization 59 (1):107-43.

Milner, Helen V., and B. Peter Rosendorff. 1997. Democratic Politics and International Trade Negotiations: Elections and Divided Government as Constraints on Trade Liberalization. Journal of Conflict Resolution 41 (1, New Games: Modeling Domestic-International Linkages):117-46.

Mitchell, Ronald B. 1994. Regime Design Matters: International Oil Pollution and Treaty Compliance. International Organization 48 (3):425-58.

Mo, Jongryn. 1994. The Logic of Two-Level Games with Endogenous Domestic Coalitions. The Journal of Conflict Resolution 38 (3):402-22.

- 1995. Domestic Institutions and International Bargaining: The Role of Agent Veto in TwoLevel Games. American Political Science Review 89 (4):914-24.

Morrow, James D., Randolph M. Siverson, and Tressa E. Tabares. 1998. The Political Determinants of International Trade: The Major Powers, 1907-90. American Political Science Review 92 (3):649-91.

Oneal, John, and Bruce Russett. 1997. The Classical Liberals Were Right: Democracy, Interdependence and Conflict, 1950-1985. International Studies Quarterly 41 (2):267-94.

Pahre, Robert. 1997. Endogenous Domestic Institutions in Two Level Games and Parliamentary Oversight of the European Union. Journal of Conflict Resolution 41 (1, New Games: Modeling Domestic-International Linkages):147-74.

Pahre, Robert, and Paul A. Papayoanou. 1997. Using Game Theory to Link Domestic and International Politics. Journal of Conflict Resolution 41 (1, New Games: Modeling DomesticInternational Linkages):4-11.

Peceny, Mark, Caroline C. Beer, and Shannon Sanchez-Terry. 2002. Dictatorial Peace? American Political Science Review 96 (1):15-26.

Przeworski, Adam, Michael E. Alvarez, Jose Antonio Cheibub, and Fernando Limongi. 2000. Democracy and Development. Political Institutions and Well-Being in the World, 1950-1990. Cambridge, MA: Cambridge University Press.

Putnam, Robert D. 1988. Diplomacy and Domestic Politics. The Logic of Two-Level Games. International Organization 42 (3):427-60.

Raknerud, Arvid, and Havard Hegre. 1997. The Hazard of War: Reassessing the Evidence for the Democratic Peace. Journal of Peace Research 34 (4):385-404.

Raustiala, Kal. 2005. Form and Substance in International Agreements. The American Journal of International Law 99 (3):581-614.

Raustiala, Kal, and David G. Victor. 1998. Conclusions. In The Implementation and Effectiveness of International Environmental Commitments: Theory and Practice, ed. D. G. Victor, K. Raustiala and E. Skolnikoff. Cambridge, MA: MIT Press.

Reinhardt, Eric. 2000. Aggresive Multilateralims: The Determinants of GATT/WTO Dispute Initiation, 1948-1998. Emory University.

Remmer, Karen L. 1998. Does Democracy Promote Interstate Cooperation? Lessons from the Mercosur Region. International Studies Quarterly 42 (1):25-51.

Rohn, Peter H. 1983. World Treaty Index. 4 vols. Santa Barbara, CA: ABC-Clio Information Services. Russett, Bruce. 1993. Grasping the Democratic Peace: Principles for a Post Cold War World. Princeton, NJ: Princeton University Press. 
Russett, Bruce, and John Oneal. 2001. Triangulating Peace: Democracy, Interdependence, and International Organizations. New York: Norton.

Saiegh, Sebastian M. 2005. Do Countries Have a "Democratic Advantage"? Political Institutions, Multilateral Agencies, and Sovereign Borrowing. Comparative Political Studies 38 (4):366-87.

Schelling, Thomas C. 1960. The Strategy of Conflict New York, NY: Oxford University Press.

Signorino, Curtis S., and Jeffrey M. Ritter. 1999. Tau-b or Nor Tau-b: Measuring the Similarity of Foreign Policy Positions. International Studies Quarterly 43 (1):115-44.

Simmons, Beth A. 1998. Compliance with International Agreements. Annual Review of Political Science 1:75-93. 2000. International Law and State Behavior: Commitment and Compliance in International Monetary Affairs. American Political Science Review 94 (4):819-35.

Simon, Michael W., and Erik Gartzke. 1996. Political System Similarity And The Choice of Allies. Do Democracies Flock Together, or Do Opposites Attract? The Journal of Conflict Resolution 40 (4):617-35.

Siverson, Randolph M., and Juliann Emmons. 1991. Birds of a Feather: Democratic Political Systems and Alliance Choices in the Twentieth Century. Journal of Conflict Resolution 35 (2, Democracy and Foreign Policy: Community and Constraint):285-306.

Slaughter, Anne-Marie. 1995. International Law and International Relations Theory: A Dual Agenda. European Journal of International Law 12 (2):205-39.

Tarar, Ahmer. 2001. International Bargaining with Two-Sided Domestic Constraints. Journal of Conflict Resolution 45 (3):320-40.

2005. Constituencies and Preferences in International Bargaining. Journal of Conflict Resolution 49 (3):383-407.

Vienna Convention on the Law of Treaties. 1969. United Nations, Treaty Series, vol. 1155.

von Stein, Jana. 2005. Do Treaties Constrain or Screen? Selection Bias and Treaty Compliance. American Political Science Review 99 (4):611-22.

Vreeland, James Raymond. 2008. The Effect of Political Regime on Civil War. Unpacking Anocracy. Journal of Conflict Resolution 52 (3):401-25.

Werner, Suzanne. 2000. The Effects of Political Similarity on the Onset of Militarized Disputes,1816-1985. Political Science Quarterly 53 (2):343-74.

World Bank, The. 2008. Economic Indicators. http://ddp-ext.worldbank.org/ext/DDPQQ. 


\section{Notes}

${ }^{1}$ Note that, although treaties are legalized agreements (Abbott et al. 2000), in this paper treaty, agreement and international instrument are used interchangeably, in consonance with the Article 2(a) of the Vienna Convention on the Law of Treaties.

${ }^{2}$ Helen Milner contemplates the existence of tacit cooperation, that is, cooperation that occurs "without communication or explicit agreement" (Milner 1992:469). This cooperation would not be accounted for when using treaties as indicators of cooperation. In Milner classification of forms of cooperation, treaties would be the archetypical example of negotiated cooperation, although it is possible and not unusual that processes of conscious policy coordination (Milner 1992:469) that does not end in the signature of a formal instrument. Note that treaties could also reflect imposed cooperation, in Milner terms.

${ }^{3}$ The claim that treaties are valid indicators of the will of cooperation is consistent with other interpretations of the origins of international treaties. From a liberal perspective, Raustiala argues that "many domestic groups demand contracts [as a type of treaty opposed to pledges or non-legal agreements] when they favor cooperation." He claims that "domestic actors that prefer cooperation exhibit a decided tendency in favor of contracts. This preference skews the supply of agreements away from what a pure functional theory would predict" (Raustiala 2005:596-597).

Further support for the use of treaties as indicators of cooperation comes from the endogeneity and selection criticisms to studies of compliance (Simmons 1998). Several scholars point out that states do not sign treaties randomly, but they commit on matters that they are willing to cooperate on (Fortna 2004; von Stein 2005).

${ }^{4}$ As Remmer points out, cooperative behavior without agreements "can reflect a variety of factors, including bureaucratic inertia, that have nothing to do with originating causes" (Remmer 1998:36).

${ }^{5}$ In a recent survey of 13,562 international treaties signed between 1875 and 2006, Estevadeordal and Suominen state that $94 \%$ of these treaties are bilateral, $5 \%$ are plurilateral (having 3-15 parties), and only $1 \%$ of them are multilateral (Estevadeordal and Suominen 2008:115-116). Miles and Posner's dataset includes all treaties signed between 1980 and 2000. Their dataset includes 38,186 bilateral and 6,925 multilateral treaties (only 667 of the multilateral are registered in the UN) (Miles and Posner 2008:26-27). Although the proportion of bilateral treaties reported by the two studies differs ( $94 \%$ and $85 \%$ ), they both support the claim of a vast majority of treaties being bilateral.

${ }^{6}$ There are numerous analyses of the influence of regime type in international relations. For examples of the variety of issues addressed in the literature, see Alvarez (2001), Bueno de Mesquita and Lalman (1992), Dai (2006), Doyle (1986), Farber and Gowa (1995), Gaubatz (1996), Kaufman (1985), Kono (2006), Lake (1992), Mansfield, Milner and Rosendorff (2000, 2002), Milner and Kubota (2005), Milner and Rosendorff (1997), Morrow, Siverson and Tabares (1998), Peceny, Beer and Sanchez-Terry (2002); Remmer (1998); Russett (1993), Saiegh (2005), Siverson and Emmons (1991).

${ }^{7}$ Examining the literature on democratic peace is beyond the scope of this paper. For a summary of this literature, see Bennett (2006:315-316). Regarding the relationship between autocracies and peace, there is mixed evidence (Peceny, Beer and Sanchez-Terry 2002:15). Whereas scholars have not found unambiguous evidence of an autocratic peace analogous to the peace between democracies (Peceny, Beer and Sanchez-Terry 2002; Russett and Oneal 2001), other works suggest that authoritarian regimes are more peaceful toward each other than mixed dyads (Gleditsch and Hegre 1997; Oneal and Russett 1997; Raknerud and Hegre 1997), and that specific types of authoritarian regimes are peaceful toward one other (Peceny, Beer and Sanchez-Terry 2002:25).

${ }^{8}$ Dai quotes the works on trade (Busch 2000; Morrow, Siverson and Tabares 1998; Reinhardt 2000; Simmons 2000), on monetary commitments (Simmons 2000), on international law (Alvarez 2001; Slaughter 1995), and on environmental policies (Raustiala and Victor 1998), among others (Dai 2002:163).

9 This finding is consistent with Simon and Gartzke's (1996) finding. Regarding alliances, they found that highly autocratic states are more likely to align with each other than are two democracies, and that most states tend to align with states of dissimilar regime types.

${ }_{10}$ This is consistent with the finding that democracies are more likely than autocracies to join PTAs (Mansfield and Reinhardt 2003:858).

${ }^{11}$ Notice that Putnam assumes the domestic win-set to be smaller than the international one.

12 A noteworthy exception is Dai (2006), who explicitly models bargaining between two autocracies. However, her argument is not a dyadic but a monadic one, and she stresses that "monadic characteristics about democratic states do not necessarily lead to dyadic predictions about democratic pairs" (Dai 2006:282). 
13 Although some of the above works explore the likely outcome of international negotiations, except for Iida (1993), they do not focus on the likelihood of reaching an agreement (signing and ratifying a bilateral treaty).

${ }_{14}$ Notice the difference between this research question and Tarar's 2001 work. Tarar asks whether "the actual size of the constraints affect[s] the final bargaining outcome" (2001:321). I do not ask for the spatial location of the agreement or for who obtains a better deal out of the treaty (Tarar 2005:385-386). This paper analyzes the likelihood of signing and consenting to be bound by a treaty, independently from the content of said treaty.

15 According to the 1969 Vienna Convention, "the consent of a State to be bound by a treaty may be expressed by signature, exchange of instruments constituting a treaty, ratification, acceptance, approval or accession, or by any other means if so agreed." (Article 11 of the Vienna Convention on the Law of Treaties 1969).

16 Iida considers this possibility "less interesting theoretically" than other causes of negotiations' breakdown (Iida 1993:406). He points two other alternatives. First, negotiations may break down because the win-sets of the negotiating countries do not intersect (although in this case, the parties should have originally [mis]perceived the existence of an overlap to start bargaining). This could be considered a change in the information available to the parties, but it could also be due to a change in at least one of the party's win-set. Second, "domestic approval does not occur with probability one" (Iida 1993:406). This last possibility, however, would not cause a negotiation breakdown, but the impossibility of formalizing the agreement (given the lack of ratification or other form of consent expression by one of the parties).

17 According to Putnam, the size of the win-sets depend on the domestic political institutions (Level II) (Putnam 1988:448).

18 The overlapping area, limited by the parties' indifference curves, is represented by $\gamma$ in Figure 2 .

19 Some scholars associate ex-ante and ex-post ratification mechanisms to parliamentary and presidential systems (Mansfield, Milner and Rosendorff 2000:305); however, there are cases of ex-ante authorizations to negotiate and sign treaties in presidential systems (for example, the fast track in the US).

20 The winning coalition is the minimal set of people whose support the incumbent needs in order to remain in power (Bueno de Mesquita et al. 2003a). As the winning coalition increases, it is likely that the constraints on the executive increase.

${ }^{21} \mathrm{~A}$ few arguments could justify expecting homogeneity to be directly related with the formalization of treaties. First, it seems plausible for similar values or norms to affect bargaining outcomes. For Iida, the existence (or the perception of the existence) of common interests is essential for international agreement and cooperation (Iida 1993:406). It seems plausible that democracies share among them a set of values and norms that may help certain overlap between their winsets. It also seems reasonable that contemporaneous autocracies share values, norms, or goals that make their win-sets closer. Second, politically similar states are argued to manage their domestic affairs in similar fashion, and be therefore less likely to disagree over domestic politics or to be involved in conflict (Werner 2000). This argument could be extended to cooperation: if homogeneous dyads have similar views of how to deal with issues, they could be expected to be more likely to have overlapping win-sets and, therefore, more likely to formalize their cooperation signing agreements.

22 According to the Article 2(a) of the Vienna Convention on the Law of Treaties, treaty is "an international agreement concluded between States in written form and governed by international law, whether embodied in a single instrument or in two or more related instruments and whatever its particular designation" (emphasis added).

${ }^{23}$ As an example of the different dynamics introduced in multilateral negotiations, Earnest shows in a recent article that coordination is easier among a large number of states than among a small group: the larger the number of parties makes reaching agreements easier (Earnest 2008).

${ }^{24}$ Examples of treaties of bilateral regime creation or modification are treaties on IGO establishment or administration. Treaties on economic activities and resources include treaties about agriculture, fisheries, transportation, communication, tourism, water, energy, etc. Treaties on trade refer to general trade, trade and payments, MFN treaties, etc.; treaties on finance include matters such as claims, debt, assets, payments, etc. The sample includes treaties on a wide variety of other issues, ranging from technical to cultural cooperation, refugees, amity, etc.

${ }^{25}$ In order to be classified as a democracy, a regime should have an elected chief executive, an elected legislature, and more than one political party. Notice that in Przeworski et al's database, autocracy is in fact a residual category, defined as non-democracy. Transition years are coded as the regime that emerges the year under consideration.

${ }^{26}$ Given that the omitted category is Autocratic dyad, a negative sign would suggest that both democracy and mixed dyads are less likely to formalize fewer bilateral treaties than joint autocracies. To test the relationship between Democratic dyad and Mixed dyad, I run models changing the omitted category.

${ }^{27}$ For rules of coding, see the Polity IV User's Manual (Marshall and Jaggers 2007).

${ }^{28}$ The effect of previous cooperation could be positive (states that have a history of formalized cooperation might find easier to reach new agreements, or past agreements might require more instruments to materialize their effects), negative 
(once issues are "solved," there is no need for more agreements on the same matter), or statistically insignificant (if both tendencies compete with each other).

29 The criteria to decide whether two countries share borders are not only territorially contiguous countries, but also countries separated by up to 24 miles of water.

30 The countries included in the sample are Argentina, Barbados, Bolivia, Brazil, Chile, Colombia, Costa Rica, Cuba, Dominican Republic, Ecuador, El Salvador, Guatemala, Guyana, Haiti, Honduras, Jamaica, Mexico, Nicaragua, Panama, Paraguay, Peru, Trinidad and Tobago, Uruguay, and Venezuela.

Countries that achieved independence after 1970 are excluded from the sample for theoretical and methodological reasons. First, I suspect that the political dynamics in recent independent countries and their success in signing treaties with other countries may be different. Second, the inclusion of countries with short life in the sample makes the sample unbalanced and not apt to perform all the statistical analyses. Finally, there is scattered data for the first years of these countries (they are dropped anyways when all controls are included in the models).

${ }^{31}$ Countries that achieve their independence after 1950 enter the dataset on that date. Note however, that information for some variables might be missing for some years after they are already independent.

${ }^{32}$ I have used Rohn's World Treaty Index (1983); it covers the period between 1850 and 1979.

${ }^{33}$ A series of Wooldridge tests for autocorrelation in panel data does not allow to reject the null hypothesis of no firstorder autocorrelation with Prob $>$ F ranging between .27 and .86 (different models). For the models including executive constraints the Prob $>$ F is . 11 .

34 Panel probit (xtprobit) is chosen over logit (xtlogit) analysis for interpretation purposes. Marginal effects can be computed after xtprobit but not after xtlogit. Random effects are the default for xtprobit analysis and the fixed effects option is not available for panel probit analysis. When fixed effects panel logit analyses are run, variables that have constant values in the dyads (such as Border and Distance) are dropped from the analyses, and 143 groups (3069 observations) are eliminated from the analysis.

35 I have computed the marginal effects using Stata 10's $m f x$ command. This command numerically calculates the marginal or partial effects and their standard errors after estimation.

${ }^{36}$ These models are not reported.

37 The impact of Affinity does not change when the dependent variable is bilateral treaties of economic cooperation, that is, when omitting treaties on security and military issues. Whereas the magnitude of the coefficient is the same $( \pm 0.005)$, the $₹$ values associated with those coefficients are slightly smaller than in the models reported in Tables 1 and 3.

38 The increase in .242 is the marginal effects of Border in Model 1(c). The marginal effect of this variable is .202 in Model 2(c), .213 in Model 3(c), and .221 in Model 4(c). In all cases, these marginal effects are statistically significant at a .01 level.

${ }^{39}$ Notice that I am testing whether similar regime types (not whether governments with similar preferences) are more prone to formalize bilateral treaties. Countries preferences are proxied and controlled by the inclusion of Affinity in these models.

${ }^{40}$ The coefficient associated to Winning coalition (dyad difference) is statistically significant not only in the reported models, but also in models omitting and/or changing control variables.

${ }^{41}$ Further tests of the homogeneity hypothesis may treat autocracies not as a homogeneous group, but taking into account different kinds of autocracies, as other scholars do (Geddes 1999; Peceny, Beer and Sanchez-Terry 2002). However, these matters are outside the scope of this paper.

${ }^{42}$ Models not reported. Data and do files included in the replication materials.

${ }^{43}$ Note that this paper's results hold when military and security treaties are excluded from the sample. 